\title{
GEOLOGY
}

UDC 622.832

\author{
M. B. Nurpeisova ${ }^{1}$, \\ orcid.org/0000-0003-0412-8469, \\ M.Zh. Bitimbayev ${ }^{1}$, \\ orcid.org/0000-0003-0870-8591, \\ K. B. Rysbekov ${ }^{1}$, \\ orcid.org/0000-0003-3959-550X, \\ Sh. Sh. Bekbasarov ${ }^{2}$, \\ orcid.org/0000-0002-8892-2506
}

https://doi.org/10.33271/nvngu/2021-6/005

1 - Satbayev University, Almaty, the Republic of Kazakhstan, e-mail: m.nurpeisova@satbayev.university

2 - Almaty University of Energy and Communications, Almaty, the Republic of Kazakhstan

\section{FORECAST CHANGES IN THE GEODYNAMIC REGIME OF GEOLOGICAL ENVIRONMENT DURING LARGE-SCALE SUBSOIL DEVELOPMENT}

Purpose. Developing the methods for forecasting changes in the geological environment based on integrated monitoring, which ensures industrial and environmental safety of Central Kazakhstan region.

Methodology. Integrated approach was used in the work, including: study on mining and geological conditions, structural features of rocks and conducting mine surveying at mines on the basis of modern methods and means of geomonitoring developed by the authors.

Findings. Methodology for integrated geodynamic monitoring system is developed. A new method of geodynamic polygon establishment is proposed. Study results were implemented at operating mining enterprises during implementation of projects "Comprehensive monitoring of slow deformation processes of the earth's surface during large-scale development of ore deposits in Central Kazakhstan" and "Development of innovative methods for forecasting and assessing the state of rock mass to prevent technogenic emergencies", and the results were used in the educational process of Satbayev University.

Originality. As a result of the research work carried out, the following were created and introduced into production:

- geodynamic polygon (GDP) of the area, established on the basis of the "nodal" method, combined with leveling, satellite and seismological points, allowing monitoring coverage of exploration and mining operations, as well as increasing efficiency of observations and reducing capital costs for mineral production;

- developed constructions of permanent (ground and underground) forced centering points (FCP), which allow increasing productivity and observations accuracy;

- method for photographing structural features of rock mass using a 3D laser scanner, which makes it possible to study elements of cracks occurrence and faults in rocks in sufficient detail;

- composition of strengthening solution from mining waste to increase stability of disturbed sections of open cast benches was developed.

The novelty of the developed methods and means is confirmed by RK patents for invention.

Practical value. Obtained results can be used to improve the level of industrial safety at mines and minimize environmental risks caused by subsoil development.

Keywords: copper ore deposits, geology, tectonics, disturbance, fracturing of rocks, geodynamic polygon, geodetic network

Introduction. One of the urgent problems during largescale mining, especially in rock massifs, is technogenic seismicity, which entails not only catastrophic technical and economic consequences (technogenic earthquakes, rock bumps, landslides, and so on), but also leading to human casualties. Technogenic earthquakes have occurred in Germany, USA, Poland, Czechoslovakia. In Russia, this problem is acute in the SUBR, in mines of the Verkhnekamensk potash deposit, and Khibiny apatite-nepheline mines [1,2].

All this is direct consequence of changes in geodynamic regime of geological environment under the influence of large-scale mining, which is convincingly confirmed by results of scientific research on the example of the "Kazakhmys" natural-technical system (NTS), which is formed by 4 underground mines and 4 open-pit mines, 5 concentrating plants, copper smelters in Karaganda, Balkhash, Zhezka-

(C) Nurpeisova M. B., Bitimbayev M.Zh., Rysbekov K. B., Bekbasarov Sh.Sh., 2021 zgan, Satpayev and corresponding infrastructure in Central Kazakhstan is powerful subject of anthropogenic impact on the environment, representing great opportunities for studying a wide range of man-made disasters and reducing their risk [3].

In recent years, development and operation of ore deposits increasingly includes objects with complex geological structure and great depth of occurrence, which requires special conditions for development of these objects. In order to avoid these difficulties in the future, it became necessary to identify additional ore reserves to extend deposit life for another $40-$ 50 years and new deposits near the cities of Zhezkazgan and Satpayev in the Ulytau region. Currently mineral resource base of Central Kazakhstan is expanding.

Literature review. The problem of man-made disasters remains relevant at the present time in all countries with developed mining industry, which is once again confirmed by materials of the next 6th International Symposium on rock bumps and mine seismicity. A lot of attention is paid to the manage- 
ment of various risks, as evidenced by the increased number of publications on this topic [4, 5].

For deposits of solid minerals, geomechanical safety of mining operations is based on engineering approaches adapted to specific mining and geological conditions of development. This approach does not take into account local structural features of underworked strata, variability of physical and mechanical properties of rocks and geomechanical characteristics of geological environment. And all this affects reliability of geomechanical assessments of real mining situations [6]. Accountability of the listed physical and geological factors in geomechanical calculations appears due to maintenance and accounting of results of geodetic observations.

In the 1960s and 1970s considerable research was carried out into the stability of rock slopes in open-pit mines. During this period early development of numerical analysis methods took place, but their use for slope stability assessment has been relatively small. Most of the works performed were focused on the use of equilibrium state methods. As pointed out in [7], for over 30 years technology for assessing the slopes stability of open-pit mines has been surprisingly less developed, but methods of equilibrium are still the most widely used. However, in recent years, the matter of safety in open pit mining has received much more attention $[8,9]$.

Necessary condition for safe and environmentally balanced development of open-pit mining is improvement of the system of monitoring and deformation observation of pit sides, slopes and dumps with the use of modern methods of surveying and high-precision deformation measurements.

These methods require in-depth knowledge of rock mass structure. Moreover, even with a detailed understanding of soil structure, it is impossible to accurately predict slope movements based on geological studies alone.

Appropriate way to overcome this problem is to use results of geodetic monitoring [10]. A number of scientists have studied application of geodetic methods for monitoring slopes using traditional geodetic equipment, namely total stations [11] and ground laser scanners [12]

Numerous studies are devoted to use of UAV photogrammetry for geodetic monitoring [13]. Today, unmanned aerial vehicles play a significant role in mining industry, since they allow not only monitoring, but also remotely determining volumes produced. In recent years, researchers have shown increasing interest in application of various radar technologies from earth to space, especially for high-precision monitoring [14]. And, of course, all mentioned methods and technologies serve as data source for prospective analysis using various GIS $[15,16]$.

Use of modern geodetic instruments (electronic tacheometers, GPS technologies and laser scanners) in geomonitoring and methods improvement of working with them, we believe, are closely related to level increasing of innovative directions. This confirms importance of methods improving of geomechanical monitoring using modern geodetic instruments as the basis for solving scientific and technical issues.

The main advantage of this method is ability to cover large areas. According to the instructions [17] ground observations are carried out twice a year with an interval of 6 months. During this time, collapse may develop and cannot be predicted. Therefore, to solve a number of mining technical problems, calculation methods must be adjusted for specific conditions, and at the same time the influence of natural and mining technical factors, as well as values variability of strength properties of rocks in space and time, etc., should be taken into account. Despite the large number of research works, the issue of forecasting and risk management of man-made disasters in view of complexity and wide variety of mining and geological features of field is still not fully resolved.

Methods. Analysis of methodology for conducting geodetic observations on the territory mined deposits is particularly related to the lack of effective methods for determining deformations scale, which necessitates methodology improvement of geodetic observations of rock deformations using modern instruments. Geodetic observations provide opportunity to identify massif deformation, which is essential for geomechanical situation assessment in mining area. This can be done only using integrated methodology of geomonitoring of change in geological environment during large-scale subsoil development [18].

Complex methodology for studying geoprocesses of NTS is original product of Satbayev University group of researchers and is effective tool to ensure maximum safety of mining operations based on the complexity of the approach used, which can be summarized as follows:

- based on the analysis of geology and region tectonics, experimental assessments of stress state and instrumental observations, fractured zones are identified in massif which define boundaries of geodynamic monitoring zone;

- then, hazardous area monitoring is organized, which includes mainly control of deformation and level of structured fracturing of massif;

- based on the results of space radar observations, a number of local centers of subsidence of earth surface over areas of underground mining were established. At present, ground observations are being carried out in this area;

- hereafter, all information about process regularity of system displacement and parameters of its critical state goes to the expert system, where, based on integration of databases and knowledge, assessment of NTS state is made and corresponding decisions on the protection of subsoil and earth's surface are justified.

Another important decision to create modern methods of geotechnical control was aimed at the development of permanent forced centering point (FCP) for installation of highprecision electronic and laser devices for geomonitoring the earth's surface, which allows ensuring speed and accuracy of centering, as well as excluding the use of tripods.

Studying issues of stress-strain state of rock mass during subsoil development were reflected in a number of works, which gave fairly complete picture of change in rock mass state under influence of anthropogenic impact, but they did not take into account the multi-scale factor confirmed by an expert system. A step in this direction was taken for the first time in Kazakhstan, which makes it possible to comprehend the whole picture, taking into account particulars, while obtaining full-fledged comprehensive assessment [19]. This work shows that a multiscale monitoring system of rock mass state at the fields of Kazakhstan is implemented, including, on the one hand, role assessment of large-scale geological objects in technogenic geomechanical processes and, on the other hand, characteristic assessment of geoprocessing on the scale of individual sections of underground mining. A distinctive feature of integrated methodology is using of an expert system at the final stage of research, where, based on integration of databases and knowledge, assessment of NTS state is made and appropriate decisions are justified. The ultimate goal of these solutions is to provide them with adaptive functioning of NTS or withdrawal of its critical state. From this position, the goal is set, research tasks and work structure are formulated.

Results. The bowels of Kazakhstan are rich in mineral deposits, including copper. Among them, special place is occupied by the Saryoba deposit located in Central Kazakhstan, $30-35 \mathrm{~km}$ north of the Zhezkazgan mine. According to the recommended methodology, geotechnical and mining-technical conditions for the development of the Saryoba deposit were studied in detail.

In general, ore field has been explored and approved with reserves in categories $\mathrm{B}+\mathrm{C} 1+\mathrm{C} 2$ in quantities that allow it to be nominated as large industrial facility. The ore field structure includes equal red-colored complex of interstratified rocks with ore-bearing deposits of the Taskuduk horizon of the Middle Carboniferous Formation Taskuduk and Serpukhov layer 
of the Lower Carboniferous. 11 ore deposits were discovered in the ore field where 109 ore bodies were explored. The largest deposits are confined to the Taskuduk horizon. Their stretch is northeastern, with length of up to $3200 \mathrm{~m}$, thickness of 0.5 to $17 \mathrm{~m}$, and dip size of up to $1400 \mathrm{~m}$ (Fig. 1).

In addition, they are complicated by both pre-ore and post-ore disjunctive disturbances, which greatly complicates their exploration and development.

According to the 2-block of recommended technique, structural features of outcrops were studied and physical and mechanical properties (PMP) of rocks were studied on samples made from cores from exploration wells. Laboratory tests of PMP of rocks were carried out in the specialized "Central Laboratory for Certification of Building Materials" (TsELSIM.). Analysis of research results of PMP of rocks made it possible to establish graphical-analytical dependences of strength properties of rock massif with the depth of their occurrence and promptly make changes in the horizon- oriented calculations of stability of pit wall (Fig. 2 and Table).

Curves of changes in the properties of rocks were carried out according to averaged indicators over the depth of $50 \mathrm{~m}$. Assessment and reliability of determining dependencies were made using formulas of mathematical statistics. Deviation of the calculated curves from the empirical ones ranges from 5-8\%, and most of them coincide with each other. The analysis of the data also shows that strength properties of rocks with depth of their occurrence change noticeably [20].

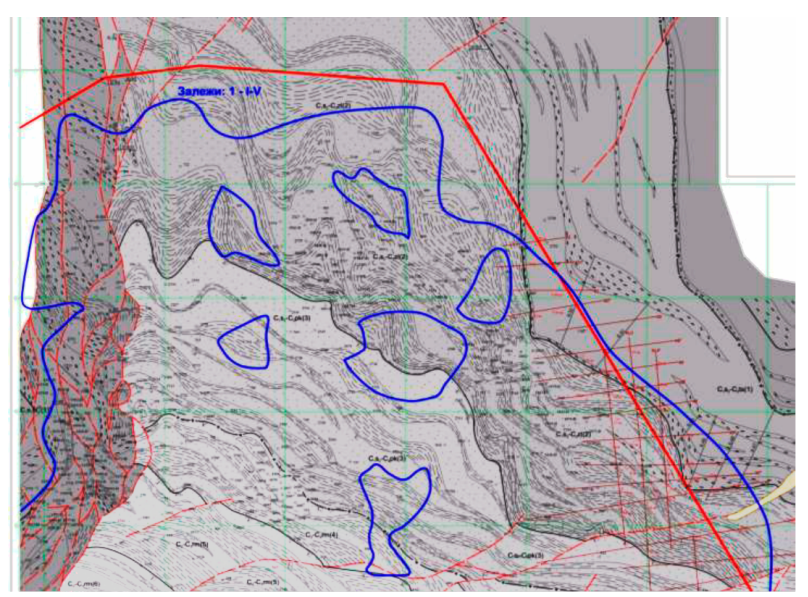

Conventional sign:

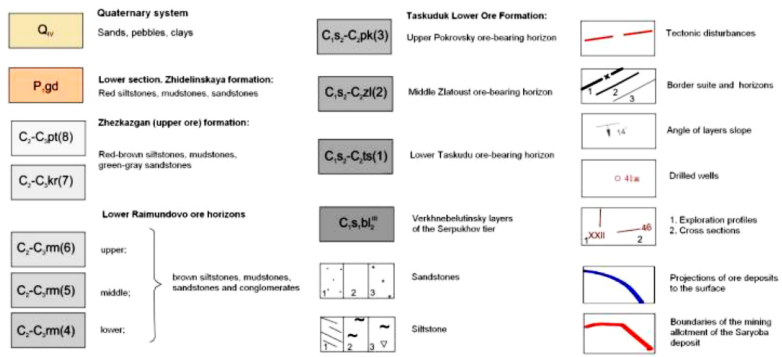

Fig. 1. Geological map of the East Saryoba field [19]
Monitoring of rock conditions, especially during exploration works on the territory of giant copper deposit, occupying large area, consisting of several deposits and occurring in various deep horizons requires creation of a high-precision geodetic justification. Based on these points of the GGN, network is being thickened. Classic option for creating geodetic networks in fields in huge area is quite laborious. It requires large financial costs for organization and production of observations. In this regard, we propose to replace extended leveling lines with local geodetic constructions in the form of profile lines and control "clusters" of geodetic and leveling points. Complex application of ground and space geodetic methods will allow monitoring observations to cover the entire territory of field, as well as increasing efficiency of observations and reducing capital costs for their production.

During large-scale and long-term development of deposits, along with geomechanical deformation processes, geodynamic processes can also develop. Therefore, during development of deep-lying ore bodies a geodynamic polygon is created, where repeated geodetic observations are carried out.

Based on the above, we propose to replace extended leveling lines with local geodetic constructions in the form of geodynamic profiles, profile lines and control "clusters" of geodetic and leveling points. Complex application of ground and space geodetic methods will allow monitoring observations to cover the entire territory of field, as well as increasing efficiency of observations and reducing capital costs for their production. Thus, for differentiated study of geodynamic and geomechanical processes of development of fields that occupy large area and are intended for deep angles, we propose to create "nodal" branches at the field, consisting of base (reference), reference (initial) and deformation geodetic and leveling points.

All nodal points are located in accordance with ore veins (Fig. 1) and are tied to points of GGS (Fig. 3).

Network of basic (reference) points is designed to assess geodynamic state of deposit territory on regional scale and serves as initial geodetic basis for developing the network of control (initial) points. In this regard, basic (reference) points should be located outside the field and influence zone of technogenic geomechanical processes due to its development, as well as at distance from tectonic fault zones. The number of basic points is determined based on the deposit outline configuration of the field and there should be at least two points.

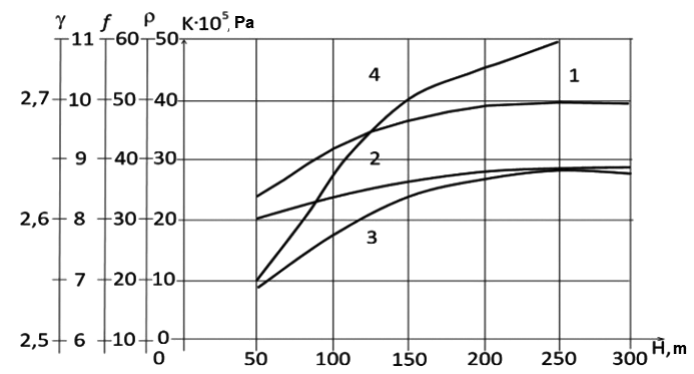

Fig. 2. Dependence of strength properties of massive cement rocks on the depth of their occurrence:

1 - adhesion - $k ; 2$ - friction angle $-\rho ; 3$ - density $-f ; 4-m e$ dium density

Equations of relations of rock properties with the depth of their occurrence

\begin{tabular}{|l|c|c|c|}
\hline \multicolumn{1}{|c|}{ Investigated value } & Function equation & Reliable value & Limits of action \\
\hline Adhesion by crack $k, \mathrm{~Pa} \cdot 10^{5}$ & $k=104.5+0.2 \mathrm{H}-0.0004 \mathrm{H} 2(1)$ & 0.88 & $300<\mathrm{H}<50$ \\
\hline Friction angle $\rho$, degrees & $\rho=25.5+0.1 \mathrm{H}-0.0002 \mathrm{H} 2(2)$ & 0.90 & $250<\mathrm{H}<50$ \\
\hline Hardness of rock $f$ & $F=6.15+0.018 \mathrm{H}-0.00003 \mathrm{H} 2(3)$ & 0.89 & $300<\mathrm{H}<50$ \\
\hline Density $\gamma, \mathrm{t} / \mathrm{m}^{3}$ & $\gamma=2.36+0.0038 \mathrm{H}-0.000008 \mathrm{H} 2(4)$ & 0.88 & $250<\mathrm{H}<50$ \\
\hline
\end{tabular}




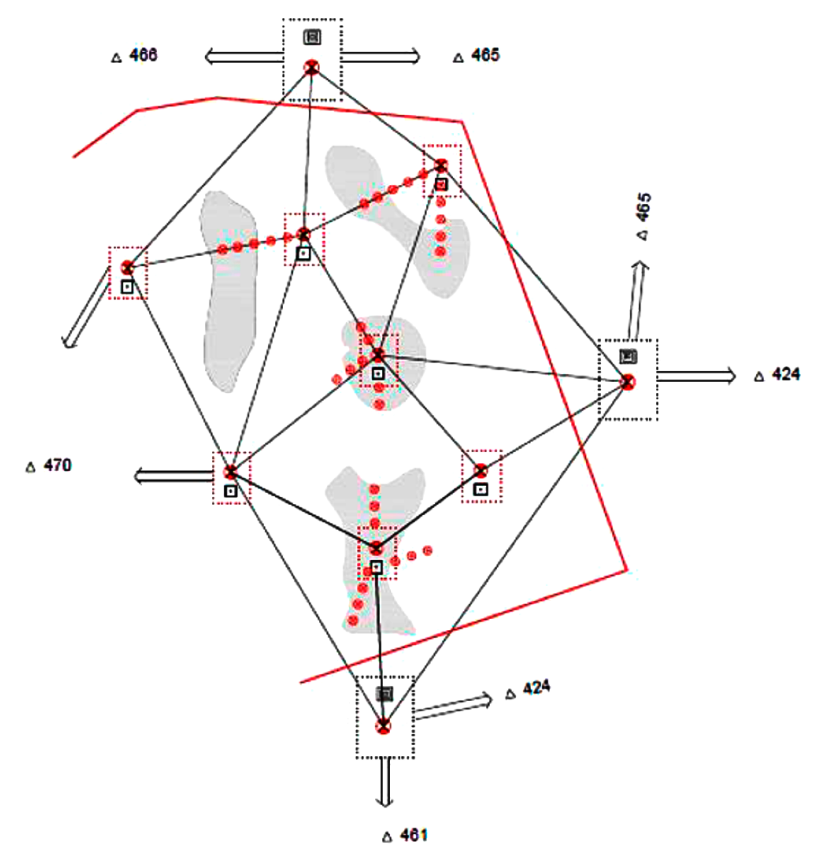

(10) Basic (reference) point

$\square$ Reference leveling station equipped with wells

- Control leveling point equipped with wells

- Ground reference

Self-centering ground benchmark

Control bush of geodetic and leveling points

Bush of basic (reference) point

D Direction to $S G N$ points

Mining allotment boundary

Ore deposits

Fig. 3. Structural scheme of observation network of geodynamic polygon [19]

Their coordinates are determined relative to GNSS stations included in the international geodetic reference network.

Network of control (initial) points is an initial geodetic basis for observing geomechanical and modern geodynamic processes in zones of tectonic disturbances, as well as for assessing the geodynamic state of the field's territory. We propose to locate control (initial) leveling points vertically off-line of the field under conditions which exclude the impact of geomechanical processes on their stability. Exploration wells existing in the field (abandoned or being put into conservation), whose base is buried below developed deposits can be used as control (initial) points.

Network of deformation points is designed for observation of technogenic, geomechanical and modern geodynamic processes.

All these works are carried out using modern geodetic technologies. Moreover, high efficiency of geodetic works is achieved only through satellite technology. Use of modern technical equipment opens up great opportunities for solving problems of geodetic support for seismic exploration at qualitatively new level. Rapid development of geodetic base centralization, profiles production on the ground with high accuracy, measurement and automation of data processing, ability to work in difficult physical, geographical and climatic conditions is carried out only on the basis of modern instruments [19].

Thus, on the basis of the GPS measurements performed, mine surveying services and observation stations of mines in Central Kazakhstan were provided with control points, whose coordinates were determined with high accuracy. Observations of absolute deformations of pit walls on researchable object were carried out on the profile lines of the observation station with instruments of new generation. Repeated geodetic measurements were carried out with electronic total stations from Leika TS110 and TS1206 in combination with reflectors and 3D scanners installed on permanent earth bench.
Long-term instrumental observations showed the laboriousness of field work, especially the transfer from one point to another set of instruments (the device itself, tripod, slats, and others). In this regard, for the installation of instruments and efficiency of measurement operations, firstly, we have developed permanent benchmark that is installed at the reference point during geomechanical monitoring (Fig. 4). The device is the geodesic center for installing new instruments. The purpose of the invention is to improve accuracy of centering, measurement efficiency in the absence of tripods at points of standing and observation. The new device allows for quick and accurate centering, and also eliminates the use of tripods [21].

Significant factor in the effective solution of the problems of modern opencast is study of fracture systems and structural block sizes. In open pit mining, rock fracturing was studied using mining compass, i. e. incidence angles of cracks and azimuths of their strike were measured with mountain compass (Fig. 4, a.)

In order to increase the efficiency of solving this issue in our mine surveying and geodetic practice, a 3D scanner was used, which made it possible to study the elements of occurrence of cracks and discontinuities (Fig. 4, $b$ ) in sufficient detail. Accuracy of shooting parameters obtained is determined by a distance between the device and object being shot [22].

Use of shooting results with a laser scanner to obtain elements of fracture occurrence and sizes of structural blocks is possible when the device is located up to 800 meters from adjacent rock mass. This gives rise to a unique opportunity to obtain information about the position of adjacent rock mass without direct performer contact. When processing the results of laser scanning, software package "MaptekI-SiteStudio" was used, where values of fracture occurrence elements are calculated: strike azimuth, slope angles and sizes of rock blocks (Fig. 5).

To obtain reliable data, starting in 2011, simultaneously with geodetic observations, a space radar survey of the Zhezkazgan field from the Radarsat-2 satellite (MDA, Canada) was organized, which makes it possible to regularly obtain the displacement field of the earth's surface with high accuracy [23].
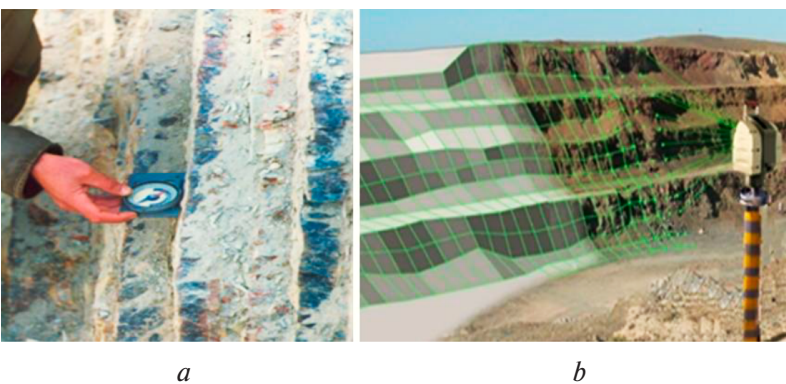

$b$

Fig. 4. Studying rock fracturing:

$a$ - surveying rock mass with mountain compass; $b$ - survey of the structure of pit wall with laser scanner installed on permanent ground reference [22]

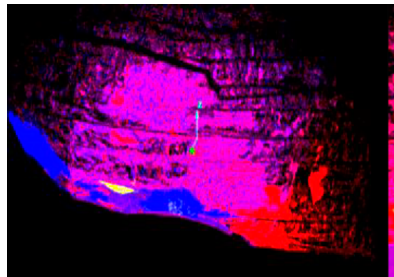

$a$

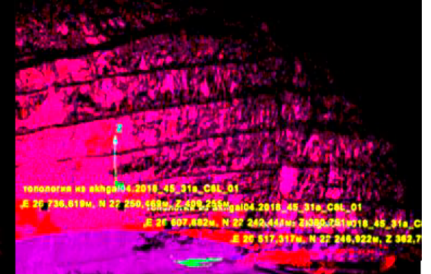

$b$
Fig. 5. Laser scanning results:

$a$-digital model of the bead; $b$-elements of crack occurrence on a computer screen 
Strength and stability of inter-chamber support pillars, as well as stability of adjacent rock mass are determined by a degree of their fracturing. Strengthening technology of fractured massif should ensure complete filling of cracks in massif with various compositions and reliably fasten individual structural blocks into a single whole [24].

Currently, research work is underway to create solutions for strengthening fractured rocks, which have low cost, sufficient fluidity to fill small cracks and adhesion to rocks, high strength.

Solution contains cement, filler and water. Mill tailings of mining and metallurgical complexes were used as filler. At the same time, a new composition was investigated and obtained for strengthening reinforcement of support points of observation station in the wells, which also makes it possible to dispose of mining waste and increase strength and frost resistance of material obtained.

The technical novelty of solution for strengthening a quarry side is confirmed by the patent of the Republic of Kazakhstan for an invention [25].

It was established that the main factor of variability in mines is the structural heterogeneity and fracturing of the rock mass. In this regard, an original method for solving the problem has been developed, which consists, on the one hand, in the operational forecast of areas of increased fracturing and geomechanical processes and, on the other hand, in the development of a special technology for increasing the strength of the rock mass by filling the cracks with the created solution.

\section{Conclusions.}

1. On the basis of analysis of domestic and foreign scientific and technical literature, work experience in the field of studying geomechanical and geodynamic processes, as well as deformation monitoring tools, complex geomonitoring technique using modern highly-accurate geodetic instruments is recommended.

2. Geological, structural and tectonic features of giant copper deposit "East Saryoba" in Kazakhstan are presented. Study on structural and strength properties of rocks made it possible not only to obtain complete information about massif state, but also to establish graphical-analytical dependence of their change on the depth of occurrence, contributing to forecast of parameters of shear zones.

3. Modern approach to setting and making observations of geodynamic and geomechanical processes in solid mineral deposits is analyzed. New "nodal" method for constructing geodetic observation systems at geodynamic test polygon has been substantiated, which allows monitoring control coverage of exploration and mining operations, as well as increasing the efficiency of observations.

4. Stability of slopes in rocky and semi-rocky formations is determined by presence of weakening surfaces and combination of their location in relation to slope. It has been proposed to use new 3D scanners along with the known methods for surveying the fracture occurrence elements and with processing of the results with the "MaptekI-SiteStudio" program. The proposed method was tested in the quarries: "Akzhalskiy", "Itauz" and "Zhairem" of central Kazakhstan.

5. Improving the stability of areas of fractured slopes of benches and underground workings is ensured by use of new reinforcing solutions based on the waste of concentration plant with the addition of suitable additive, which makes it possible to dispose of mining waste, reduce cement costs by $45-50 \%$ and, finally, improve geomechanical situation at mines.

Acknowledgements. This research is funded by the Science Committee of the Ministry of Education and Science of the Republic of Kazakhstan "Complex monitoring of slow deformation processes of the earth's surface during large-scale development of ore deposits in Central Kazakhstan (Grant No. 08857097)".

\section{References.}

1. Mikhailova, N. N., \& Uzbekov, A. N. (2018). Tectonic and manmade earthquakes in Central Kazakhstan. News of NAS RK. Series of geology and technical sciences, (3), 137-145.
2. Kozerev, A. A., Panin, V. I., \& Semenova, I. E. (2018). Geodynamic safety of mining operations in rock-burst hazardous conditions on the example of the Khibiny apatite deposits. FTPRPI, (5), 33-44. https:// doi.org/10.17580/gzh.2020.09.03.

3. Rylnikova, M. V., Yun, A. B., \& Terentyeva, I. V. (2016). Replenishment of retired capacities of mines at the stage of finalizing balance reserves of the deposit - condition for the environmentally balanced development of the Zhezkazgan region. Mine Surveying, (5), 6-10. 4.Trubetskoy, K. N. (2020). State and main directions of integrated development and conservation of resources of the earth's interior. In Problems and prospects of integrated development and conservation of the earth's interior, (pp. 5-11). Moscow: IPKON RAN, master Konferentsii. Retrieved from https://xn--80apgmbdfl.xn--plai/wp-content/up loads $2020 / 11 / \% \mathrm{D} 0 \% \mathrm{~A} 1 \% \mathrm{D} 0 \% \mathrm{~B} 1 \% \mathrm{D} 0 \% \mathrm{BE} \% \mathrm{D} 1 \% 80 \% \mathrm{D} 0 \% \mathrm{BD} \%$ D0\%B8\%D0\%BA 4 \%D0\%BA\%D0\%BE\%D0\%BD\%D1\%84 \%D $0 \% 98 \% \mathrm{D} 0 \% 9 \mathrm{~F} \% \mathrm{D} 0 \% 9 \mathrm{~A} \% \mathrm{D} 0 \% 9 \mathrm{E} \% \mathrm{D} 0 \% 9 \mathrm{D} \% \mathrm{D} 0 \% \mathrm{~A} 0 \% \mathrm{D} 0 \% 90$ $\%$ D0\%9D_2020.pdf.

5. Drzewiecki, J., \& Myszkowski, J. (2018). Mining-induced seismicity of a seam located in rock mass made of thick sandstone layers with very low strtngh and deformation parameters. Journal of Sustainable Mining, 17(4), 167-174.

6. Miletenko, I. V., Miletenko, N.A., \& Odintsev, V. N. (2013). Modeling induced dislocation in host rocks around excavations. Journal of Mining Science, 49(6), 847-853.

7. Babets, D., Sdvyzhkova, O., Shashenko, O., Kravchenko, K., \& Cabana, E.C. (2019). Implementation of probabilistic approach to rock mass strength estimation while excavating through fault zones. Mining of Mineral Deposits, 13(4), 72-83. https://doi.org/10.33271/ mining 13.04.072.

8. Sdvizhkova, Ye. A., Kovrov, A. S., \& Kiriiak, K. K. (2014). Geomechanical assessment of landslide slope stability by finite element method. Naukovyi Visnyk Natsionalnoho Hirnychoho Universytetu, (2), 86-92. 9. Trubetskoy, K. N., \& Rylnikova, M. V. (2015). Condition and perspectives of development of open-pit mining in XXI century. GIAB, S1(1), 21-32. https://doi.org/10.15593/2712-8008/2021.3.7.

10. Narendranathan, S., \& Nikraz, H. (2011). Optimal System Design for Instrumented Slope Monitoring in Open Pit Mines. International Conference on Advances in Geotechnical Engineering, Perth, Australia, 7-9, (pp. 311-317). Corpus ID: 110608751.

11. Rákay, Š., Zuzik, J., Weiss, G., \& Labant, S. (2013). Surveying of inaccessible rock faces and volume calculation of the irregular solids using robotic total station. Acta Montanistica Slovaca, 18(3), 164-171. 12. Bazarnik, M. (2018). Slope stability monitoring in open pit mines using 3D terrestrial laser scanning. AG $2018-4^{\text {th }}$ International Conference on Applied Geophysics, E3S Web of Conferences, 66, 01020. https:// doi.org/10.1051/e3sconf/20186601020.

13. Blistan, P., Kovanič, L., Patera, M., \& Hurčík, T. (2019). Evaluation quality parameters of DEM generated with low-cost UAV photogrammetry and Structure-from-Motion (SfM) approach for topographic surveying of small areas. Acta Montanistica Slovaca, 24(3), 198-212. https://doi.org/10.36487/ACG_repo/2025_11.

14. Ajay Kumar, \& Ritika Rathee (2017). Monitoring and evaluating of slope stability for setting out of critical limit at slope stability radar. International Journal of Geo-Engineering, 8(18). https://doi. org/10.1186/s40703-017-0054-y.

15.Theilen-Willige, B., Ait Malek, H., Charif, A., El Bchari, F., \& Chaïbi, M. (2014). Remote Sensing and GIS Contribution to the Investigation of Karst Landscapes in NW-Morocco. Geosciences, 4(2), 50-72. https://doi.org/10.3390/geosciences4020050.

16. Chalkias, C., Ferentinou, M., \& Polykretis, C. (2014). GIS-Based Landslide Susceptibility Mapping on the Peloponnese Peninsula, Greece. Geosciences, 4(3), 176-190. https://doi.org/10.3390/geosciences 4030176

17. Instructions for observing the movement of rocks and earth's surface during underground mining of ore deposits (2012). Moscow: Nedra. Retrieved from https://meganorm.ru/Data2/1/4293826/4293826028.htm.

18. Sashurin, A.D., Balek, A.E. \& Panzhin, A.A. (2017). An innovative technology for diagnosing the geodynamic activity of the geological environment and assessing the safety of subsoil use objects. Gorny Zhurnal, (12), 16-20. https://doi.org/10.17580/gzh. 2017.12.03.

19. Nurpeisova, M.B., Bitimbayev, M.Zh., Rysbekov, K. B., \& Shults, R. (2020). Geodetic substantiation of the Saryarka copper ore region. News of the National Academy of Sciences of the Republic of Kazakhstan. Series of Geology and Technical Sciences, 6, 194-202. https:// doi.org/10.32014/2020.2518-170X.147.

20. Aitkazinova, S., Soltabaeva, S., Kyrgizbaeva, G., Rysbekov, K., \& Nurpeisova, M. (2016). Methodology of assessment and prediction of critical condition of natural-technical systems. International Multi- 
disciplinary Scientific GeoConference Surveying Geology and Mining Ecology Management, SGEM, 2, 3-10. https://doi.org/10.5593/ sgem 2016/b22/s09.001.

21. Ormambekova, A. E. (2020). Permanent ground reference used in geomonitoring of the earth's surface. (Kazakhstan Patent No. 1586). Committee on Intellectual Property Rights Ministry of Justice of the Republic of Kazakhstan.

22. Nurpeisova, M. B., Kirgizbayeva, D. M., \& Kopzhasaruly, K. (2016). Innovative methods of the rock massif fractures survey and treatment of its results. Naukovyi Visnyk Natsionalnoho Hirnychoho Universytetu, (2), 11-18.

23. Mansurov, V., Satov, M., \& Kantemirov, Y. (2012). Satellite radar monitoring of land and buildings subsidence over Zhezkazgan cooper field, (pp. 77-83). Moscow: Geomatics. Retrieved from https://sovzond.ru/press-center/geomatics/2012-01/.

24. Rysbekov, K., Huayang, D., Kalybekov, T., Sandybekov, M., Idrissov, K., Zhakypbek, Y., \& Bakhmagambetova, G. (2019). Application features of the surface laser scanning technology when solving the main tasks of surveying support for reclamation. Mining of Mineral Deposits, 13(3), 40-48. https://doi.org/10.33271/mining13.03.040.

25. Nurpeisova, M. B., Kirgizbayeva, D. M., \& Bek, A.A. (2018). Composition for strengthening fractured rocks. Utility model patent No. 1573. News of NAS RK. Series of geology and technical sciences, (3), 137-145. Retrieved from https://kazpatent.kz/images/bulleten/2016/ gazette/pdf/2-201608.pdf.

\section{Прогноз зміни геодинамічного режиму геологічного середовища при великомасштабному освоєнні надр}

\section{М. Б. Нурпеісова ${ }^{1}$, М. Ж. Бітімбаєв ${ }^{1}$, К. Б. Рисбеков ${ }^{1}$, Ш. Ш. Бекбасаров ${ }^{2}$}

1 - Satbayev University, м. Алмати, Республіка Казахстан, e-mail: m.nurpeisova@satbayev.university

2 - Алматинський університет енергетики та зв'язку, м. Алмати, Республіка Казахстан

Мета. Розробка методики прогнозу змін геологічного середовища на основі комплексного моніторингу, що забезпечує промислову та екологічну безпеку регіону Центрального Казахстану

Методика. У роботі використано комплексний підхід, що включає: вивчення гірничо-геологічних умов, структурних особливостей гірських порід родовищ і ведення геомоніторингу на рудниках, на основі розроблених авторами сучасних способів і засобів моніторингу.

Результати. Розроблена методика ведення комплексної системи геодинамічного моніторингу. Запропоновано новий метод створення геодинамічного полігону. Результати дослідження впроваджені на діючих гірничодобувних підприємствах при виконанні проектів «Комплексний моніторинг повільних деформаційних процесів земної поверхні при великомасштабному освоєнні рудних родовищ Центрального Казахстану» $\mathrm{i}$ «Розробка інноваційних методів прогнозування та оцінки стану масиву гірських порід для попередження надзвичайних ситуацій техногенного характеру», а також використані в навчальному процесі Satbayev University.

Наукова новизна. У результаті проведених НДР створені та впроваджені у виробництво:

- геодинамічний полігон району, створеного на основі «вузлового» методу, поєднаний із нівелірними, супутниковими й сейсмологічними пунктами, що дозволяе охопити моніторинговим контролем розвідувальні й гірничі роботи, що проводяться, а також підвищити оперативність спостережень і знизити капітальні витрати на видобування корисних копалин;

- розроблені конструкції постійних (наземних і підземних) пунктів примусового центрування, що дозволяють підвищити продуктивність робіт і точність спостережень;

- спосіб зйомки структурних особливостей масивів за допомогою лазерного 3D сканера, що дозволяє досить докладно вивчити елементи залягання тріщин і розривних порушень гірських порід;

- склад зміцнюючого розчину з відходів гірничого виробництва для підвищення стійкості порушених ділянок уступів кар'єра.

Новизна розроблених способів і засобів підтверджені патентами РК на винахід.

Практична значимість. Отримані результати можуть бути використані для підвищення рівня виробничої безпеки на копальнях і мінімізації екологічних ризиків, викликаних освоєнням надр.

Ключові слова: міднорудні родовища, геологія, тектоні$\kappa a$, порушеність, тріщинуватість гірських порід, геодинамічний полігон, геодезична мережа

The manuscript was submitted 23.02.20. 